\title{
Antibiotic sensitivity patterns of penicillinase- positive and penicillinase-negative strains of Neisseria gonorrhoeae isolated in Fukuoka, Japan
}

\author{
SHIN-ICHI YOSHIDA,* SHINJI URABE, † AND YASUO MIZUGUCHI* \\ From the *Department of Microbiology, School of Medicine, University of Occupational and \\ Environmental Health, Kitakyushu, and +Urabe Hospital, Fukuoka, Japan
}

SUMMARY Penicillinase production and minimum inhibitory concentrations (MICs) of penicillin G, amoxycillin, doxycycline, and spectinomycin were studied for 155 gonococcal strains isolated in Fukuoka, Japan, between April and December 1981. Of 155 isolates, $25(16 \cdot 1 \%)$ strains were identified as penicillinase-producing Neisseria gonorrhoeae (PPNG) by a rapid iodometric test. The antibiotic sensitivity of 130 penicillinase-negative (non-PPNG) and 25 PPNG strains was compared. The mean MIC of penicillin G for non-PPNG strains was $0.65 \mu \mathrm{g} / \mathrm{ml}$. Twenty-five PPNG strains had MICs of penicillin G between $6 \cdot 25$ and $>100 \mu \mathrm{g} / \mathrm{ml}$. The susceptibility to amoxycillin and doxycycline of PPNG strains was significantly lower than that of non-PPNG strains. All the strains proved to be sensitive to spectinomycin. The MICs of four antibiotics for non-PPNG strains were significantly correlated.

\section{Introduction}

Over the past 20 years there has been a progressive increase in the prevalence of strains of Neisseria gonorrhoeae showing resistance to penicillin. ${ }^{1-5} N$ gonorrhoeae was previously susceptible to penicillin. Both the frequency of occurrence and the degree of resistance of strains of the organism, however, have increased very slowly, as is reflected in the minimum inhibitory concentrations (MICs) of penicillin. ${ }^{1-5}$

Penicillinase-producing $N$ gonorrhoeae (PPNG) strains were isolated for the first time in 1976 in the United Kingdom ${ }^{6-8}$ and in the United States ${ }^{9}$ and since then have been found in many countries. ${ }^{10-21}$ An especially high incidence of PPNG has been reported from countries in South-east Asia, such as Malaysia, Thailand, and the Philippines.

We report the trends in antibiotic susceptibility of gonococci and the incidence of PPNG in Fukuoka City, Japan.

\section{Materials and methods}

Specimens were collected from patients with gonorrhoea who attended Urabe Hospital between

Address for reprints: Dr S Yoshida, Department of Microbiology, School of Medicine, University of Occupational and Environmental Health, Kitakyushu, 807 Japan

Accepted for publication 24 March 1982
April and December 1981. Specimens were taken from the urethra in men and from the urethra, vagina, and endocervix in women. Gram-stained smears of exudate were examined microscopically and $N$ gonorrhoeae was cultured on GC medium base (Difco) enriched with $1 \%$ bacto-haemoglobin and $1 \%$ Isovitalex (BBL) supplemented with $0 \cdot 2$ $\mu \mathrm{g} / \mathrm{ml}$ lincomycin and 2 units $/ \mathrm{ml}$ colistin.

\section{IDENTIFICATION OF GONOCOCCI}

After incubation for 24 hours at $37^{\circ} \mathrm{C}$ in candleextinction jars colonies of organisms were examined by Gram stain microscopy and oxidase reaction; their ability to produce acid from glucose, lactose, maltose, and sucrose was tested in the Minitek system (BBL). Their ability to reduce nitrate was also evaluated.

\section{ANTIBIOTIC SUSCEPTIBILITY TEST}

In-vitro antibiotic testing of the gonococc $n$ l isolates was performed by the plate dilution method. Using a spectrophotometer bacterial suspensions were adjusted to $1 \times 10^{6}$ organisms $/ \mathrm{ml}$ and one loopful (about $1 \times 10^{4}$ colony-forming units) was streaked on to GC agar plates containing serial dilutions of antibiotics in concentrations of $0.025-100 \mu \mathrm{g} / \mathrm{ml}$. The plates were incubated for 24 hours at $37^{\circ} \mathrm{C}$ in a candle jar. The concentration of antibiotic required to produce total inhibition of growth constituted the 
minimum inhibitory concentration (MIC) for the isolates tested.

\section{RAPID IODOMETRIC METHOD}

The production of $\beta$-lactamase by gonococcal isolates was examined by a rapid iodometric method. ${ }^{22}$

\section{STATISTICAL ANALYSIS}

The difference between the mean MICs of antibiotics was tested by the Mann-Whitney U-test. Rank correlation coefficient between paired antibiotics was measured by Spearman's method and the significance of correlation coefficient evaluated. MICs of $<0.025$ and $>100 \mu \mathrm{g} / \mathrm{ml}$ were included in the values for 0.025 and $100 \mu \mathrm{g} / \mathrm{ml}$ respectively.

\section{Results}

Of 155 isolates of $N$ gonorrhoeae, $25(16 \cdot 1 \%)$ produced penicillinase.

The susceptibility of isolates to penicillin G, amoxycillin, doxycycline, and spectinomycin was measured in concentrations ranging from 0.025 to $100 \mu \mathrm{g} / \mathrm{ml}$. The MICs of these antibiotics for 130 penicillinase-negative (non-PPNG) and 25 PPNG strains are shown in table I. The mean MIC for penicillin $\mathrm{G}$ of non-PPNG strains was $0.65 \mu \mathrm{g} / \mathrm{ml}$. Only 22 of $155(14 \cdot 2 \%)$ isolates were inhibited by $\leqslant 0.1 \mu \mathrm{g} / \mathrm{ml}$ of penicillin G. Sixty-nine of 155 $(44 \cdot 5 \%)$ strains required $\geqslant 1 \cdot 56 \mu \mathrm{g} / \mathrm{ml}$ of penicillin $\mathrm{G}$ to be inhibited. One non-PPNG strain had an MIC of penicillin G of $50 \mu \mathrm{g} / \mathrm{ml}$; its MICs for amoxycillin, doxycycline, and spectinomycin were also high $(6 \cdot 25$, 50 , and $25 \mu \mathrm{g} / \mathrm{ml}$ respectively). PPNG strains had
MICs of penicillin G between $6 \cdot 25$ and $>100 \mu \mathrm{g} / \mathrm{ml}$ and of amoxycillin between $12 \cdot 5$ and $>100 \mu \mathrm{g} / \mathrm{ml}$.

There was a significant difference between the mean MIC of doxycycline for PPNG and that for non-PPNG strains. No significant difference was found, however, between the mean MIC of spectinomycin for PPNG and that for non-PPNG strains. Spectinomycin-resistant strains were not detected. Rank correlation coefficients for paired antibiotics were calculated using MICs for nonPPNG strains (table II). Moderate correlations were found for susceptibility to penicillin G, amoxycillin, and doxycycline, while lower correlations usually occurred with the antibiotics paired with spectinomycin.

TABLE II Rank correlation coeffficients (r) of the in-vitro susceptibility of $N$ gonorrhoeae to antibiotics

\begin{tabular}{|c|c|c|}
\hline Antibiotics & $r$ & Probability \\
\hline $\begin{array}{l}\text { Penicillin G and amoxycillin } \\
\text { Penicillin G and doxycycline } \\
\text { Penicillin G and spectinomycin } \\
\text { Amoxycillin and doxycycline } \\
\text { Amoxycillin and spectinomycin } \\
\text { Doxycycline and spectinomycin }\end{array}$ & $\begin{array}{l}0.687 \\
0.611 \\
0.246 \\
0.379 \\
0.396 \\
0.209\end{array}$ & $\begin{array}{l}\mathrm{P}<0.001 \\
\mathrm{P}<0.001 \\
0.001<\mathrm{P}<0.01 \\
\mathrm{P}<0.001 \\
\mathrm{P}<0.001 \\
0.01<\mathrm{P}<0.05\end{array}$ \\
\hline
\end{tabular}

\section{Discussion}

In this study we found that the occurrence of less sensitive and resistant strains of $N$ gonorrhoeae to penicillin was very high in Fukuoka City. Of 155 isolates, $69(44 \cdot 5 \%)$ required $\geqslant 1.56 \mu \mathrm{g} / \mathrm{ml}$ of penicillin $\mathrm{G}$ to be inhibited. Moreover, 25 of 155 $(16 \cdot 1 \%)$ isolates were identified as PPNG. The mean

TABLE I In-vitro susceptibility of isolates of $N$ gonorrhoeae to antibiotics

\begin{tabular}{|c|c|c|c|c|c|c|c|c|}
\hline \multirow[b]{2}{*}{$M I C(\mu g / m l)$} & \multicolumn{2}{|l|}{ Penicillin $G$} & \multicolumn{2}{|l|}{ Amoxycillin } & \multicolumn{2}{|l|}{ Doxycycline } & \multicolumn{2}{|c|}{ Spectinomycin } \\
\hline & \multirow{2}{*}{$\frac{\text { Non-PPNG }}{1}$} & \multirow{2}{*}{$P P N G$} & Non-PPNG & $P P N G$ & Non-PPNG & $P P N G$ & Non-PPNG & $P P N G$ \\
\hline$<0.025$ & & & 1 & & 1 & & & \\
\hline 0.025 & 1 & & & & & & & \\
\hline 0.05 & 6 & & 2 & & & & & \\
\hline $0 \cdot 1$ & 14 & & 3 & & & & & \\
\hline $0 \cdot 2$ & 16 & & 4 & & & & & \\
\hline 0.39 & 28 & & 20 & & 10 & & & \\
\hline 0.78 & 20 & & 36 & & 11 & & & \\
\hline $1 \cdot 56$ & 10 & & 45 & & 30 & 3 & 6 & 1 \\
\hline 3.13 & 18 & & 18 & & 22 & 1 & 8 & 3 \\
\hline $6 \cdot 25$ & 12 & 4 & 1 & & 15 & 2 & 8 & \\
\hline 12.5 & 3 & 2 & & 2 & 18 & 7 & 53 & 5 \\
\hline 25 & & 5 & & 3 & 8 & 5 & 54 & 16 \\
\hline 50 & 1 & 6 & & 3 & 12 & 7 & 1 & \\
\hline 100 & & 7 & & 5 & 3 & & & \\
\hline$>100$ & & 1 & & 12 & & & & \\
\hline Total No of strains & 130 & 25 & 130 & 25 & 130 & 25 & 130 & $\begin{array}{c}25 \\
15.76\end{array}$ \\
\hline $\begin{array}{l}\text { Mean MIC }(\mu \mathrm{g} / \mathrm{ml}) \\
U_{\text {-test** }}^{*}\end{array}$ & 0.65 & $36 \cdot 20$ & 0.98 & $67 \cdot 56$ & $4 \cdot 22 \quad P<0$. & $14 \cdot 70$ & $13 \cdot 72$ & \\
\hline
\end{tabular}

NS = not significant; PPNG = penicillinase-producing $N$ gonorrhoeae

*Mann-Whitney U-test 
MIC of penicillin $\mathrm{G}$ was $0.65 \mu \mathrm{g} / \mathrm{ml}$ for all except penicillinase-producing strains. The first infection due to PPNG in Japan was reported by Onoda et al ${ }^{18}$ in 1979; the actual date of isolation was 1977. In this study almost all infections with PPNG strains were acquired around Fukuoka City. The incidence of PPNG strains in Fukuoka City was lower than that of Thailand $(1977-79 ; 18 \cdot 5 \%)^{14}$ and Singapore (1979; $19 \cdot 2 \%)^{20}$ but higher than that of Riyadh (1979-80; $12 \%) .{ }^{13}$ The epidemiology of gonorrhoea caused by PPNG strains will be reported in detail elsewhere.

Recently, Shtibel ${ }^{23}$ reported two strains of gonococci showing high resistance to penicillin; the MIC of penicillin for both strains was $50 \mathrm{IU} / \mathrm{ml}$. In our present study one of the non-PPNG strains showed high resistance to penicillin G (MIC of penicillin $50 \mu \mathrm{g} / \mathrm{ml}$ ). The occurrence of strains of $N$ gonorrhoeae which are highly resistant to penicillin but which did not produce $\beta$-lactamase has to be considered when chemotherapy is being planned.

There was a significant difference between the mean MIC of doxycycline for PPNG and that for non-PPNG strains. The reason for this is not clear at present. A significant difference was not observed, however, between the mean MIC of spectinomycin for PPNG and that for non-PPNG strains.

A relatively high correlation between the sensitivity to penicillin $G$ and doxycycline was observed among non-PPNG strains. These two antibiotics are structurally different but both have small molecular weights and are hydrophilic. They are thought to pass through the porin proteins in the outer membrane. ${ }^{24}$ Alteration of the porin proteins of gonococci may modify the susceptibility to these two antibiotics.

Recently, spectinomycin-resistant gonococcal strains have been reported. ${ }^{25}$ Such strains were not, however, observed in this study.

We thank Dr Tohru Doi, Department of Human Ecology, University of Occupational and Environmental Health, Japan, for his help in the statistical analysis.

\section{References}

1. Gründer K, Petzoldt D. Sensitivity of Neisseria gonorrhoeae to spectinomycin and thiamphenicol. BrJ Vener Dis 1980;56:252-4.
2. Watko LP, Brownlow WJ. Antibiotic susceptibility of Neisseria gonorhoeae isolated in the Western Pacific in 1911. Br J Vener Dis 1975;51:34-7.

3. Martin JE jun, Lester A, Price EV, Schmale JD. Comparative study of gonococcal susceptibility to penicillin in the United States, 1955-1969. J Infect Dis 1970;122:459-61.

4. Petzoldt D, Gründer K, Neubert U. Sensitivity of Neisseria gonorrhoeae to penicillin in West Germany. Br J Vener Dis 1979;55:80-2.

5. Silver PS. Penicillin-insensitive gonococci in the Bolton area. Preponderance in young women and immigrants. $\mathrm{Br} J$ Vener Dis 1971; 47:367-72.

6. Phillips I. $\beta$-lactamase-producing, penicillin-resistant gonococcus. Lancet 1976;ii:656-7

7. Percival A, Rowlands J, Corkill JE, et al. Penicillinaseproducing gonococci in Liverpool. Lancet 1976; ii:1379-82.

8. Perine PL, Thornsberry C, Schalla W, et al. Evidence for two distinct types of penicillinase-producing Neisseria gonorrhoeae. Lancet 1977;ii:993-5.

9. Ashford WA, Golash RG, Hemming VG. Penicillinaseproducing Neisseria gonorrhoeae. Lancet 1976;ii:657-8.

10. Arya OP, Rees E, Percival A, Alergant CD, Annels EH, Turner GC. Epidemiology and treatment of gonorrhoea caused by penicillinase-producing strains in Liverpool. $\mathrm{Br} J$ Vener Dis 1978;54:28-35

11. Bijkerk H. Penicillinase-producing gonococci in the Netherlands. Br J Vener Dis 1980;56:243.

12. Blog FB, Chang A, De Koning GAJ, Pranje AP, Stolz E. Penicillinase-producing strains of Neisseria gonorrhoeae isolated in Rotterdam. Br J Vener Dis 1977;53:98-100.

13. Chowdhury MNH, Pareek SS, Mahgoub E-S. Penicillinaseproducing Neisseria gonorrhoeae in Riyadh, Saudi Arabia. Br J Vener Dis 1981;57:256-8.

14. Crum JW, Duangmani C, Vibulyasekha S, Suthisomboon K. Resistance to penicillin and identification of penicillinaseproducing Neisseria gonorrhoeae among clinical isolates in Thailand. Antimicrob Agents Chemother 1980;18:360-1.

15. Jaffe HW, Biddle JW, Johnson SR, Wiesner PJ. Infections due to penicillinase-producing Neisseria gonorrhoeae in the United States; 1976-1980. J Infect Dis 1981;144:191-7.

16. Johnston NA, Kolator B, Seth AD. A survey of $\beta$-lactamaseproducing gonococcal isolates reported in the United Kingdom 1979-80. The present trend. Lancet 1981;i:263-4.

17. Nayyar KC, Noble RC, Michel MF, Stolz E. Gonorrhoea in Rotterdam caused by penicillinase-producing gonococci. $\mathrm{Br} J$ Vener Dis 1980;56:244-8.

18. Onoda Y, Mitsui I, Obara Y, Yamai S, Miyamoto Y, Ashizawa $M$. Initial isolation of a strain of Neisseria gonorrhoeae producing $\beta$-lactamase (PPNG) in Japan. Chemotherapy 1979;27:265-8.

19. Piot P. Resistant gonococcus from the Ivory Coast. Lancet $1977 ; \mathrm{i}: 857$

20. Rajan VS, Thirumoorthy T, Tan NJ. Epidemiology of penicillinase-producing Neisseria gonorrhoeae in Singapore. $\mathrm{Br}$ $J$ Vener Dis 1981;57:158-61.

21. Urabe S, Yoshida S. Six cases of gonorrhea caused by penicillinase-producing Neisseria gonorrhoeae (PPNG). Nishinihon J Urol 1981;43:937-41.

22. Anonymous. Neisseria gonorrhoeae-producing penicillinase. Weekly Epidemiological Record 1976;51:293-4.

23. Shtibel R. Non- $\beta$-lactamase-producing Neisseria gonrorhoeae highly resistant to penicillin. Lancet $1980 ; \mathrm{i}: 39$.

24. Nikaido H, Nakae T. The outer membrane of Gram-negative bacteria. Adv Microb Physiol 1979;20:163-250.

25. Ashford WA, Potts DW, Adams HJU, et al. Spectinomycinresistant penicillinase-producing Neisseria gonorrhoeae. Lancet 1981;ii:1035-7. 